Two Minds: Artists and Architects in Collaboration

J. Fernie (ed.)

London, Black Dog Publishing, 2006, 175 pp., £24.95, hardback, ISBN 1904772269

p. 505

This book is primarily an exploration of eighteen place-specific projects undertaken in Britain, all of which evince some sort of collaboration between an artist and an architect. Each of these partnerships stemmed from the Royal Society for the Encouragement of Arts, Manufactures and Commerce's 'Art for Architecture' scheme, set up in 1991. They are all therefore 'public projects' according to the definition provided here (i.e. "funded through the public purse", p. 13). It is worth noting that Jes Fernie - the book's editor - ran the RSA scheme for six years (19982004). One may well question whether she is the best person to critically evaluate something with which she herself has been so closely associated.

Leaving that to one side, and before turning to the case studies, a word ought to be said about the two opening essays. The first is written by a curator in Zurich, the second by one in Los Angeles. This, Fernie explains, was done "[i]n a bid to extend the oddly parochial reach of much art in the public domain" (p. 12). This strikes me as rather disingenuous: the decision surely had at least as much to do with a commercial publisher wishing to sell a book to a wide European and North American market. Any academic who has tried to get an 'oddly parochial' study past a commissioning editor will know all about this. But perhaps I will be the only reader to question the inequitable juxtaposition between Los Angeles' embarrassment of riches and the financially doomed Earth Centre at Doncaster.

An alternative approach might have been to link the contextual essays far more explicitly to the work of the RSA. All sorts of evaluative methods could have been used to assess the projects (something of a moral consideration given that they were supported by public money). Fernie explains that there have been 135 RSA projects.

So why were precisely these 18 selected for this book? Were the other 117 'unsuccessful' or just not very interesting? On what criteria should we judge? Who is qualified to say? In short, how have the projects fared "in the world of use and misuse" (Tony Fretton, cited p. 124)? In the 18 case studies too little is said about "the dynamics of social interaction" (p. 163), beyond an artist 
saying nice things about an architect or, just occasionally, an architect saying nasty things about an artist.

Whilst there are examples of fruitful collaboration here, the endeavours that did not work are the most memorable: not least the clash between Richard Meier - architect of the one billion dollar Getty Museum (1984-1997) - and the landscape architect Robert Irwin (p. 40). Meier's instant antipathy toward Irwin, exacerbated by Meier's apparent desire to design everything, runs counter to what Fernie describes as "an endearing vulnerability shown by architects" (p. 13). (Incidentally,

\section{p. 506}

architects are seemingly not the only vulnerable thing about this book: it was falling to pieces by the time I had finished reading it. Let us hope that the projects that it describes have a longer lifespan.)

Two Minds gets rather vague when the projects under review go awry. Mark Dion and Eelco Hooftman's amicable but ultimately only 'virtual' collaboration at Doncaster's Earth Centre is given a positive spin: at least by not doing anything concrete they avoided "woeful interference from money men" (p. 68). Richard Wentworth and Charlie MacKeith had a similarly difficult time of it at Manchester Museum (1997-2003). Their friendship was "tested" and their project "threatened" "by the machinations of an institution averse to change" ( $p$. 104). Whilst this book gives us tantalising glimpses of such machinations, it does not, in the final analysis, critically engage with them. Perhaps, as has already been suggested, a closer connection between the essays and the case studies would have achieved this critical edge. That said, Fernie does attempt to draw some wider conclusions in her introduction. These mostly consist of trying to provide some stereotypical distinctions between artists and architects - with the former seeming to thrive on "contemporary problems" whilst the latter try to avoid them like the plague (p. 13).

Fernie's book, which is pleasantly designed, is colour-coded into three neat sections, namely: green for Groundscapes, blue for Buildings and turd-brown for Things. It should be noted, however, that there are thankfully few examples of the 'turd in the plaza' approach to public art here (p. 85). Instead, the art that we find in Two Minds more often than not adopts the "consultative approach" (p. 53). If only there had been more written about the interaction between the art and its public, we would have learnt far more about the projects under review. The best thing that can be said about 
this book is that it inspires the reader to find out more. To do so one must overcome the initial sense of disappointment that the very short chapters inspire. A case in point is the potentially fascinating section on Derry's Gasyard Centre. Locky Morris and Michael Hegarty collaborated from 2001 to 2003 "on the reconfiguration of interior spaces such as the cafe, reception and exhibition area" ( $p$. 100). So it comes as some surprise to note that the accompanying photograph shows the exterior of the building. On the preceding page there is a brilliant blue map showing Londonderry in 1799. It is accompanied by a caption which tells us that "Morris' research into the history of the area fed directly into his collaboration with Michael Hegarty and the Bogside community" (pp. 98-99). But what history and how did it 'feed in'? Given Bogside's Bloody Sunday heritage, this must have been a particularly fraught undertaking - but of this we only get the barest of glimpses.

One of the very best chapters is about Tania Kovats and the Ikon Gallery in Birmingham (1994-1997). Fernie identifies this as marking "an important changing point in the way that artists worked with architects on public buildings and landscape projects in the UK" (p. 85). Be that as it may, the experience for Kovats even though she herself describes it as being "of lasting significance" (p. 86) - resulted in her being "desperate not to collaborate with anyone on any aspect of her work" (p. 88). I have visited the Ikon Gallery many times, both on my own and with student groups. I did not know that Kovats had provided a 'plinth' for the building by encasing the original curtain wall in black slate. Fernie eloquently sums up the effect of this intervention: "Kovats turned the plinth into a sign of itself, making the

\section{p. 507}

building the focus of attention in the same way that sculpture on a plinth is the focal point in a gallery" (p. 88). It is only after reading this that I can appreciate just why it is that this former Victorian school creates such a lasting impression and manages to define itself so successfully in such a radically transformed urban landscape. And this is where this book proved its real value, by opening my eyes to something I have seen but never properly understood.

\section{Stuart Burch}

Nottingham Trent University, UK 